ISSN : $1410-7252$

Vol. 18 No. 01 Juni 2016

\title{
PENTINGNYA PROMOSI GUNA MENINGKATKAN MINAT WISATAWAN WISATA SEJARAH DI KOTA LAMA SEMARANG
}

\author{
Dewi Hermin Sutanto ${ }^{1}$ \\ Erick Shandy $\mathbf{H}^{2}$ \\ Program Diploma Kepariwisataan Universitas Merdeka Malang ${ }^{1}$ \\ Jl. Bandung No. 1 Malang
}

Korespodensi dengan Penulis:

Dewi Hermin S: Telp: 628123593185

E-mail: shienny_petra@yahoo.com

\begin{abstract}
The tourism industry has excellent prospects in moving the economy that can reliably increase the revenue of the country, broaden and flatten the opportunity to strive and their new jobs for people, especially stakeholder in tourism. Development of tourism in Indonesia is not separated from the development in each area in Indonesia. One of them is Semarang, Central Java, which has the rich culture and history that can be used as a tourist attractions. One area that is currently being intensively developed, exploring the potential of Semarang, giving the opportunities for tourism businesses for the society in Central Java. The purpose of this research is to determine how far the importene of promotion to increase tourist interest in history tourism at old town Semarang. The result of the questionnaire which addressed to domestic tourist, the writer condude as follows: 1) circumstances and historical tourism potential of old city in Semarang is very attractive for the visitors, but in terms of management and the facilities both of them are need to be improved, 2) Human resources is less skilled and less experienced in tourism so they need to train their skill to participate in developing the potential and visitors attractions. The method used is descriptive method by collecting data and identifity the problems that exist in old town Semarang.
\end{abstract}

Keywords: Promotion, tourists, history tourism.

\begin{abstract}
Abstraksi
Industri pariwisata mempunyai prospek yang sangat baik dalam menggerakkan perekonomian yang dapat diandalkan untuk meningkatkan penerimaan devisa negara, memperluas dan meratakan kesempatan dalam berusaha serta adanya lapangan kerja baru bagi masyarakat khususnya insan pariwisata. Perkembangan pariwisata di Indonesia pun tak lepas dari pengembangan di daerah-daerah. Salah satunya adalah Kota Semarang,Jawa Tengah yang menyimpan kekayaan budaya dan sejarah yang dapat dijadikan obyek wisata. Salah satu daerah yang saat ini sedang gencar-gencarnya untuk dikembangkan, Melihat kekayaan potensi yang dimiliki oleh Kota Semarang, membuka peluang usaha jasa pariwisata bagi insan-insan pariwisata di Propinsi Jawa Tengah . Dalam mengadakan penelitian di Kota Semarang, khususnya di Kota Lama Semarang penulis memiliki tujuan yaitu : Untuk mengetahui sejauh mana
\end{abstract}


Pentingnya Promosi Dalam Upaya Meningkatkan Minat Wisatawan sejarah di Kota Lama Semarang Dari hasil kuesioner yang ditujukan kepada wisatawan domestik, dapat ditarik kesimpulan sebagai berikut : 1) Keadaan dan potensi wisata sejarah yang dimiliki oleh Kota Semarang sangat menunjang guna menarik perhatian dari para wisatawan untuk berkunjung namun jika dilihat dari segi pengelolaan dan ketersediaan sarana dan prasarana, maka mengurangi minat dari wisatawan untuk berkunjung; 2) SDM yang kurang terampil dan berpengalaman di bidang Pariwisata akan menghambat pengembangan dari potensi dan daya tarik pengunjung. Metode yang di gunakan adalah metode deskriptif dengan mengumpulkan data dan mengindetifkasi masalah yang ada di wisata kota lama Semarang.

Kata kunci : Promosi , minat wisatawan, wisata sejarah

Saat ini dunia pariwisata sudah menjadi sebuah industri yang berkembang untuk mendapatkan keuntungan sebesar-besarnya. Perkembangan dunia pariwisata ditunjang dengan semakin kondusifnya kondisi dan tatanan ekonomi, politik, sosial, budaya, dan keamanan. Kemajuan teknologi, informasi dan komunikasi turut memberikan andil besar dalam perkembangan pariwisata di Indonesia. Dengan kemajuan teknologi dan informasi memungkinkan produk wisata dipromosikan dan ditampilkan di dalam suatu halaman situs internet sehingga dapat dilihat dan dibaca oleh orang di seluruh dunia.

Pemerintah dan masyarakat perlu bekerjasama dalam usaha untuk memajukan suatu daerah tujuan wisata dengan produk wisata yang diunggulkan paling tidak perlu memperhatikan tiga faktor yaitu daya tarik dari destinasi, fasilitas dari destinasi, dan kemudahan dari destinasi. Daya tarik merupakan faktor utama wisatawan dalam memutuskan untuk berkunjung ke daerah tujuan wisata.

Fasilitas yang disediakan oleh penyelenggara merupakan sarana yang memudahkan bagi pengunjung untuk dapat memenuhi kebutuhannya selama mereka berkunjung sehingga diharapkan pengunjung tidak merasa kesulitan memenuhi kebutuhannya (akomodasi dan transportasi). Fasilitas yang menjadi kemudahan bagi pengunjung daerah tujuan wisata banyak ditentukan oleh kelengkapan informasi dan ketersediaan transportasi. Kelengkapan informasi 
tersebut seharusnya sangat mudah didapat di setiap media promosi yang disediakan oleh penyelenggara wisata. Sedangkan ketersediaan transportasi seharusnya sudah menjadi komitmen yang terjalin di antara pihak penyelenggara dan pihak pendukung obyek wisata baik dari kalangan masyarakat maupun swasta.

Demikian pula daerah tujuan obyek wisata kota Semarang, tidak ketinggalan berusaha secara terus menerus mengembangkan produk wisatanya agar menarik wisatawan. Produk wisata sejarah yang sangat unik menjadikan optimisme yang besar bagi pemerintah daerah setempat untuk terus mendukung upaya-upaya dalam perkembangan obyek wisata sejarah terutama mengenai obyek obyek sejarah peninggalan gedung gedung lama di kota semarang

Hingga saat ini belum ada peneliti yang khusus menggali informasi tentang obyek wisata sejarah peninggalan jaman belanda yang berupa gedung gedung dengan potensi pariwisatanya. Informasi yang valid tentang perkembangan wisata dan potensi yang dikandung seharusnya sering dilakukan agar ditemukan cara-cara yang paling tepat dalam pengembangan potensi wisatanya. Oleh karena itu peneliti berusaha melakukan penelitian yang mendalam agar dapat memperoleh data dan informasi yang diperlukan dan dapat digunakan dalam pengembangan daerah tersebut. Dalam hal ini peneliti ingin mengetahui apakah para pengunjung ke kota Semarang sudah merasakan efektifitas promosi dan informasi yang disediakan oleh Pemerintah Daerah Propinsi Jawa Tengah, khususnya Pemerintah Kota Semarang

Kota Lama Semarang adalah suatu kawasan di Semarang yang menjadi pusat perdagangan pada abad 1920 . Pada masa itu, untuk mengamankan warga dan wilayahnya, maka kawasan itu dibangun benteng, yang dinamai benteng Vijhoek. Untuk mempercepat jalur perhubungan antar ketiga pintu gerbang dibenteng itu maka dibuat jalan-jalan perhubungan, dengan jalan utamanya dinamai : Heeren Straat. Saat ini bernama Jl. Let Jen Soeprapto. Salah satu lokasi pintu benteng yang ada sampai saat ini 
adalah Jembatan Berok, yang disebut De Zuider Por.

Kawasan Kota Lama Semarang disebut juga Outstadt. Luas kawasan ini sekitar 31 hektare. Dilihat dari kondisi geografi, nampak bahwa kawasan ini terpisah dengan daerah sekitarnya, sehingga nampak seperti kota tersendiri, sehingga mendapat julukan "Little Netherland". Kawasan Kota Lama Semarang ini merupakan saksi bisu sejarah Indonesia masa kolonial Belanda lebih dari 2 abad, dan lokasinya berdampingan dengan kawasan ekonomi. Di tempat ini ada sekitar 50 bangunan kuno yang masih berdiri dengan kokoh dan mempunyai sejarah Kolonialisme di Semarang. Bangunan di Kota Lama Semarang Secara umum karakter bangunan di wilayah ini mengikuti bangunanbangunan di benua Eropa sekitar tahun 1700-an. Hal ini bisa dilihat dari detail bangunan yang khas dan ornamen-ornamen yang identik dengan gaya Eropa. Seperti ukuran pintu dan jendela yang luar biasa besar, penggunaan kaca-kaca berwarna, bentuk atap yang unik, sampai adanya ruang bawah tanah
Seperti kota-kota lainnya yang berada di bawah pemerintahan kolonial Belanda, dibangun pula benteng sebagai pusat militer. Benteng ini berbentuk segi lima dan pertama kali dibangun di sisi barat kota lama Semarang saat ini. Benteng ini hanya memiliki satu gerbang di sisi selatannya dan lima menara pengawas. Masing-masing menara diberinama: Zeeland, Amsterdam, Utrecht, Raamsdonk dan Bunschoten. Pemerintah Belanda memindahkan pemukiman Cina pada tahun 1731 di dekat pemukiman Belanda, untuk memudahkan pengawasan terhadap segala aktifitas orang Cina. Oleh sebab itu, Benteng tidak hanya sebagai pusat militer, namun juga sebagai menara pengawas bagi segala aktifitas kegiatan orang Cina.

\section{METODE}

\section{A. Definisi Operasional Variable \\ 1. Promosi}

Promosi merupakan salah satu variable dalam bauran pemasaran yang sangat penting dilakukan oleh perusahaan dalam memasarkan produk. Kegiatan promosi bukan saja berfungsi sebagai alat komunikasi 
antara perusahaan dengan konsumen, melainkan juga sebagai alat mempengaruhi konsumen dalam kegiatan pembelian atau penggunaan jasa sesuai dengan keinginan dan kebutuhannya.

\section{Menarik Minat Wisatawan}

Bahwa minat wisatawan atau "tourist attraction", istilah yang lebih sering digunakan, yaitu segala sesuatu yang menjadi daya tarik bagi orang untuk mengunjungi suatu daerah tertentu.

\section{B. Ruang Lingkup Penelitian}

Adapun ruang lingkup penelitian yang di lakukan khususnya berorientasi pada promosi dan transportasi obyek wisata sejarah untuk meningkatkan kunjungan wisatawan di Kota Semarang, Jawa Tengah

\section{Lokasi Penelitian}

Lokasi yang menjadi tempat penelitian di dalam kota semarang tepatnya didaerah yang disebut sebagai kota lama. Kawasan Kota Lama Semarang disebut juga Outstadt. Luas kawasan ini sekitar 31 hektare. Dilihat dari kondisi geografi, nampak bahwa kawasan ini terpisah dengan daerah sekitarnya, sehingga nampak seperti kota tersendiri, sehingga mendapat julukan "Little Netherland". Kawasan. Di tempat ini ada sekitar 50 bangunan kuno yang masih berdiri dengan kokoh dan mempunyai sejarah Kolonialisme di Semarang. Secara umum karakter bangunan di wilayah ini mengikuti bangunan-bangunan di benua Eropa sekitar tahun 1700-an. Hal ini bisa dilihat dari detail bangunan yang khas dan ornamenornamen yang identik dengan gaya Eropa. Seperti ukuran pintu dan jendela yang luar biasa besar, penggunaan kaca-kaca berwarna, bentuk atap yang unik, sampai adanya ruang bawah tanah

\section{Sumber Data}

Adapun sumber data yang di peroleh sebagai bahan untuk penyusun ini diantaranya:

1. Data Primer

Data yang dikumpulkan penulis selama penelitian berjalan dan diperoleh dari lokasi penelitian

2. Data Sekunder

Data yang di peroleh penulis dari tinjauan buku-buku kepustakaan.

\section{E. Teknik Pengumpulan Data}


Dalam proses pengumpulan

data yang di peroleh, penulis

melakukan dengan cara :

1. Observasi

2. DokumentasI

3. Wawancara

F. Teknik Analisa Data

Teknik yang di gunakan penulis yaitu teknik analisa dan dikripsi kualitatif, yang memaparkan secara sistematis tentang data yang di peroleh selama penelitian.

Untuk mengetahui sejauh mana peran promosi dan tranportasi di obyek wisata sejarah kota lama dalam upaya meningkatkan kunjungan wisatawan di Kota semarang akan di gunakan sebagai prosentasi berdasarkan tanggapan responden dari kuesioner yang di ajukan.

\section{HASIL DAN PEMBAHASAN}

\section{Sebab Masalah}

Yang menjadi penyebab terjadinya masalah adalah Pemerintah setempat dalam hal ini diwakili oleh Dinas Pariwisata Daerah belum dapat berperan dengan maksimal, sehingga pengelolaan obyek wisata sejarah, termasuk di obyek wisata Kota lama Semarang, kurang diminati Hal ini dapat kita lihat bahwa: tidak ada atau kurangnya.reklame-reklame maupun brosur mengenai fasilitas yang ada di lokasi ,dan tidak adanya SDM yang mengelola obyek wisata yang berada dilokasi sehingga tidak ada yang memberikan informasi tentang fasilitas fasilitas yang dimiliki di obyek wisata, dan juga kurangnya ke aneka ragaman atraksi wisata dan sehingga membuat banyak wisatawan yang kecewa.

\section{Akibat Masalah}

Akibat yang timbul dari permasalahan adalah wisatawan kurang tertarik pada obyek wisata sejarah yang ada di Kota Semarang termasuk sejarah Kota lama di Semarang ,karena tidak adanya informasi apa-apa baik fasilitas ataupun atraksinya, juga saranasarana yang ada di sekitar lokasi wisata masih kurang terpelihara dan kesannya kumuh dan kusam juga tidak adanya sarana pembelian souvenir atau oleh-oleh, kurangnya informasi atau promosi tentang obyek wisata yang ada 
ISSN : $1410-7252$

\section{Bukti Masalah}

Tabel 01. Kuisoner

Promosi wisata sejarah di wisata Kota lama Semarang

\begin{tabular}{|c|c|c|c|c|c|}
\hline \multirow{2}{*}{ No } & \multirow{2}{*}{ Pernyataan } & \multicolumn{2}{|c|}{ Ya } & \multicolumn{2}{|c|}{ Tidak } \\
\hline & & Jml & $\%$ & $\mathrm{Jml}$ & $\%$ \\
\hline 1 & $\begin{array}{l}\text { Obyek wisata sejarah dipublikasi baik di media cetak maupun } \\
\text { di brosur }\end{array}$ & 2 & 20 & 8 & 80 \\
\hline 2 & $\begin{array}{l}\text { Pihak pengelola mempromosikan tentang obyek wisata } \\
\text { sejarah dan kota lama Semarang, melalui televisi maupun radio }\end{array}$ & 2 & 20 & 8 & 80 \\
\hline 3 & $\begin{array}{l}\text { Obyek lokasi wisata sejarah maupun Kota lama Semarang } \\
\text { pernah dipublikasikan disetiap kota atau daerah untuk Iebih } \\
\text { menjadi daya tarik wisata yang potensial }\end{array}$ & 4 & 40 & 6 & 60 \\
\hline 4 & $\begin{array}{l}\text { Sejauh ini sudah terdengar promosi yang dilakukan Dinas } \\
\text { Pariwisata melalui Koran/Majalah }\end{array}$ & 3 & 30 & 7 & 70 \\
\hline 5 & $\begin{array}{l}\text { Sumber daya manusia yang bertugas di lokasi obyek wisata } \\
\text { sudah dilakukan pembenahan dan pelatihan tentang promosi }\end{array}$ & 4 & 40 & 6 & 60 \\
\hline 6 & $\begin{array}{l}\text { Fasilitas yang disediakan di obyek wisata sejarah kota lama } \\
\text { Semarang sudah sesuai iklan }\end{array}$ & 3 & 30 & 7 & 70 \\
\hline 7 & $\begin{array}{l}\text { Cara promosi obyek wisata yang dilakukan pengelola sudah } \\
\text { menarik }\end{array}$ & 2 & 20 & 8 & 80 \\
\hline 8 & Atraksi wisata yang ada sudah sesuai dengan brosur & 3 & 30 & 7 & 70 \\
\hline 9 & $\begin{array}{l}\text { Brosur obyek wisata sejarah di Kota Semarang di sebar di } \\
\text { Agen Travel atau Biro Perjalanan }\end{array}$ & 6 & 60 & 4 & 40 \\
\hline 10 & $\begin{array}{l}\text { Obyek wisata sejarah di Kota Lama Semarang, sudah } \\
\text { mempunyai atraksi yang menarik }\end{array}$ & 5 & 50 & 5 & 50 \\
\hline & Rata-rata & & $34 \%$ & & $66 \%$ \\
\hline
\end{tabular}

Responden : 10 staff bagian promosi Dinas Pariwisata

\section{Keterangan :}

N\% : Prsentase responden yang memberikan jawaban

N : Responden memberi jawaban

$\Sigma \quad$ : Jumlah responden

$\mathrm{Ya}=660 / 10 \times 100 \%=34 \%$ 
Tidak $=340 / 10 \times 100 \%=66 \%$

Hasil kuisener

1. Pernyataan pertama adalah $20 \%$ menjawab ya dan $80 \%$ menjawab tidak, jadi disimpulkan bahwa sebagian orang mengetahui obyek wisata sejarah di Kota Semarang, termasuk kota lama Semarang bukan dari Koran, / brosur.

2.Pernyataan kedua adalah 20\% menjawab ya dan $80 \%$ menjawab tidak, jadi dapat disimpulkan bahwa promosi jarang dilakukan di Kota Semarang terutama mengenai obyek wisata sejarah kota lama Semarang sangat kurang.

3.Pernyataan ketiga adalah $40 \%$ responden menjawab ya dan $60 \%$ menjawab tidak, dengan kesimpulan bahwa obyek wisata sejarah di Kota lama Semarang, termasuk Kota Semarang pernah atau masih memerlukan pembenahan cara publikasinya.

4.Pernyataan keempat adalah 30\% responden menjawab ya dan $70 \%$ menjawab tidak, dengan kesimpulan promosi yang dilakukan oleh Pihak Pengelola/pemerintah melalui surat kabar/majalah masih belum maksimal atau masih kurang.

5. Pernyataan kelima adalah $40 \%$ responden menjawab ya dan $60 \%$ responden menjawab tidak, dengan ini dapat disimpulkan bahwa SDM yang bertugas di lokasi obyek wisata masih perlu menambah pelatihan tentang promosi

6.Pernyataan keenam adalah 30\% responden menjawab ya dan $70 \%$ responden menjawab tidak, hal ini dapat disimpulkan bahwa fasilitas fasilitas yang ada di obyek wisata tersebut harus dilengkapi untuk menambah kepuasan pengunjung.

7. Pernyataan ketujuh adalah $20 \%$ responden menjawab ya dan $80 \%$ menjawab tidak, dengan ini dapat diketahui promosi tentang obyek wisata yang ada masih harus ditingkatkan dan lebih diperjelas.

8. Pernyataan kedelapan adalah $30 \%$ responden menjawab ya dan $70 \%$ responden menjawab tidak, hal ini dapat disimpulkan bahwa atraksi wisata masih perlu di informasikan lebih jelas dan sesuai dengan yang ada 
9. Pernyataan kesembilan $60 \%$ responden menjawab ya dan $40 \%$ responden menjawab tidak, dengan ini disimpulkan bahwa hanya sebagian orang yang mengetahui obyek wisata itu dari Agen Travel atau Biro Perjalanan setempat

10. Pernyataan kesepuluh 50\% responden menjawab ya dan 50\% responden menjawab tidak, dapat disimpulkan bahwa sebagian orang sudah merasa tidak cukup dengan atraksi yang diadakan di obyek wisata

\section{Kesimpulan Hasil Kuisoner}

Dari hasil kuisener 34\% wisatawan menjawab Ya dan 66\% wisatawan menjawab Tidak, kesimpulankesimpulan yang diambil maka dapat diketahui masalah yang ada seperti kekurangan pengenalan melalui promosi pada obyek wisata, seperti publikasi, baik melalui media,televisi,radio dan juga masalah transportasi serta SDM perlu ditingkat kualitas kerjanya. Guna menarik minat wisatawan agar banyak berkunjung pada objek wisata sejarah Kota Semarang terutama obyek wisata
Kota lama Semarang maka masih banyak lagi aspek yang perlu diperhatikan dan dikembangkan oleh pihak pengelola diantaranya pengembangan sarana dan prasarana pariwisata terutama sistem komunikasi agar memudahkan wisatawan dalam mendapatkan informasi terkait dengan objek yang ada. Pengelolaan Obyek wisata sejarah Kota lama Semarang itu sendiri juga memerlukan sumber daya manusia yang memiliki keahlian dan kreatifitas yang tinggi untuk dapat, enciptakan kreatifitas atau keunikan tersendiri pada objek tersebut agar dapat dikunjungi. Kenyataan yang ada di Kota Semarang khususnya pada objek wisata sejarah Kota lama Semarang menunjukkan bahwa sumber daya manusia dibidang pariwisata sangat terbatas hal ini memerlukan perhatian yang serius demi pemecahan masalah yang ada yakni dengan jalan memberikan pendidikan dan pembinaan baik formal maupun non formal dibidang kepariwisataan, agar dapat menciptakan sumber daya manusia yang dapat mengelola Kota lama Semarang sebagai wisata sejarah yang unik dalam rangka menarik 
minat wisatawan. Dipihak lain dan pengelola khususnya dalam promosi tentang keberadaan objek promosi objek wisata sangat wisata disuatu daerah itu sangat diperlukan karena promosi objek penting sehingganya dalam pengelolaan objek wisata sejarah Kota lama Semarang sekarang ini masih dalam tahap promosi antara orang per orang. Peranan Pemerintah umumnya

wisata ini memerlukan kerja sama
yang baik antara Pemerintah dan
pemilik audio visual untuk menarik
para pengunjung untuk datang ke
objek $\quad$ wisata tersebut.

\section{Tabel 02. Kuisener}

Minat wisatawan di obyek wisata sejarah Kota lama Semarang

\begin{tabular}{|c|c|c|c|c|c|}
\hline \multirow{2}{*}{ No } & \multirow{2}{*}{ Pernyataan } & \multicolumn{2}{|c|}{$\mathrm{Ya}$} & \multicolumn{2}{|c|}{ Tidak } \\
\hline & & Jml & $\%$ & $\mathrm{Jml}$ & $\%$ \\
\hline 1 & $\begin{array}{l}\text { Pengunjung/wisatawan sering berkunjung ke obyek wisata } \\
\text { sejarah Kota lama Semarang }\end{array}$ & 2 & 20 & 8 & 80 \\
\hline 2 & Wisatawan/pengunjung tinggal lebih lama di Kota Semarang & 2 & 20 & 8 & 80 \\
\hline 3 & $\begin{array}{l}\text { Pengunjung datang ke obyek wisata karena mendapat brosur/ } \\
\text { publikasi }\end{array}$ & 4 & 40 & 6 & 60 \\
\hline 4 & $\begin{array}{l}\text { Pengunjung/wisatawan datang ke obyek wisata sejarah Kota } \\
\text { lama Semarang karena ada promosi dari pemerintah }\end{array}$ & 3 & 30 & 7 & 70 \\
\hline 5 & Pengunjung mengetahui obyek wisata dari teman/ saudara & 6 & 60 & 4 & 40 \\
\hline 6 & $\begin{array}{l}\text { Atraksi di obyek wisata sudah memenuhi keinginan } \\
\text { pengunjung/wisatawan }\end{array}$ & 6 & 60 & 4 & 40 \\
\hline 7 & $\begin{array}{l}\text { Cara promosi obyek wisata yang dilakukan pengelola kurang } \\
\text { menarik }\end{array}$ & 8 & 80 & 2 & 20 \\
\hline 8 & Atraksi wisata yang ada sudah sesuai dengan brosur & 7 & 70 & 3 & 30 \\
\hline 9 & $\begin{array}{l}\text { Pengunjung/wisatawan datang ke obyek wisata sejarah Kota } \\
\text { lama Semarang karena ada keunikannya }\end{array}$ & 6 & 60 & 4 & 40 \\
\hline 10 & $\begin{array}{l}\text { Wisatawan / pengunjung datang ke obyek wisata melalui } \\
\text { paket tour/promo }\end{array}$ & 5 & 50 & 5 & 50 \\
\hline & Rata-rata & & $49 \%$ & & $51 \%$ \\
\hline
\end{tabular}


Responden : 10 wisatawan/pengunjung

Keterangan :

N\% : Prsentase responden yang memberikan jawaban

$\mathrm{N} \quad$ : Responden memberi jawaban

$\Sigma \quad$ : Jumlah responden

$\mathrm{Ya} \quad=490 / 10 \times 100 \%=49 \%$

Tidak $=510 / 10 \times 100 \%=51 \%$

Hasil kuisoner

1. Pernyataan pertama adalah $20 \%$ menjawab ya dan $80 \%$ menjawab tidak, jadi disimpulkan bahwa sebagian orang jarang atau tidak mengetahui obyek wisata sejarah terutama wisata sejarah Kota lama Semarang

2.Pernyataan kedua adalah 20\% menjawab ya $80 \%$ menjawab tidak, jadi dapat disimpulkan bahwa tidak ada pengunjung/ wisatawan yang tinggal lama di obyek wisata sejarah kota lama Semarang

3.Pernyataan ketiga adalah $40 \%$ responden menjawab ya dan $60 \%$ menjawab tidak, dengan kesimpulan bahwa obyek wisata sejarah Kota lama Semarang diketahui wisatawan bukan karena publikas atau promosi.
4.Pernyataan keempat adalah 30\% responden menjawab ya dan $760 \%$ menjawab tidak, dengan kesimpulan promosi yang dilakukan oleh Pihak Pengelola/pemerintah melalui surat kabar/majalah masih belum maksimal atau masih kurang.

5. Pernyataan kelima adalah $60 \%$ responden menjawab ya dan $40 \%$ responden menjawab tidak, dengan ini dapat disimpulkan bahwa pengunjung/wisatawan dating ke obyek wisata dari kawan atau saudaranya

6.Pernyataan keenam adalah 60\% responden menjawab ya dan $40 \%$ responden menjawab tidak, hal ini dapat disimpulkan bahwa atraksi maupun fasilitas fasilitas yang ada di obyek wisata tersebut sudah cukup bagi pengunjung. 
7. Pernyataan ketujuh adalah $80 \%$ responden menjawab ya dan $20 \%$ menjawab tidak, dengan ini dapat diketahui promosi tentang obyek wisata yang ada masih harus ditingkatkan dan lebih diperjelas.

8. Pernyataan kedelapan adalah $70 \%$ responden menjawab ya dan 30\% responden menjawab tidak, hal ini dapat disimpulkan bahwa atraksi wisata masih perlu ditingkatkan lagi dan ditambah

9. Pernyataan kesembilan $60 \%$ responden menjawab ya dan $40 \%$ responden menjawab tidak, dengan ini disimpulkan bahwa obyek wisata sejarah Kota lama Semarang mempunyai keunikan

10. Pernyataan kesepuluh 50\% responden menjawab ya dan 50\% responden menjawab tidak, dapat disimpulkan bahwa sebagian orang sudah merasa cukup dengan promosi yang ada diobyek wisata dengan adanya paket wisata dengan promosi

\section{Kesimpulan Hasil Kuisener}

Dari hasil kuisener 49\% wisatawan menjawab Ya dan 51\% wisatawan menjawab Tidak, kesimpulan- kesimpulan yang diambil maka dapat diketahul masalah yang ada seperti kekurangan peranan promosi pada obyek wisata,seperti publikasi, baik melalui media,televise,radio dan juga masalah transportasi serta SDM perlu ditingkat kualitas kerjanya. Sehingga minat wisatawan/pengunjung tidak mengetahui atau obyek wisata tersebut agar banyak berkunjung pada objek wisata sejarah Kota Semarang terutama obyek wisata sejarah Kota lama Semarang maka masih banyak lagi aspek yang perlu diperhatikan dan dikembangkan oleh pihak pengelola diantaranya pengembangan sarana dan prasarana pariwisata terutama sistem komunikasi agar memudahkan wisatawan dalam mendapatkan informasi terkait dengan objek yang ada. Pengelolaan Obyek wisata sejarah Kota lama Semarang itu sendiri juga memerlukan sumber daya manusia yang memiliki keahlian dan kreatifitas yang tinggi untuk dapat ,menciptakan kreatifitas atau keunikan tersendiri pada objek tersebut agar dapat dikunjungi. Kenyataan yang ada di Kota Semarang khususnya pada objek wisata sejarah Kota lama Semarang 
menunjukkan bahwa sumber daya manusia dibidang pariwisata sangat terbatas hal ini memerlukan perhatian yang serius demi pemecahan masalah yang ada yakni dengan jalan memberikan pendidikan dan pembinaan baik formal maupun non formal dibidang kepariwisataan, agar dapat menciptakan sumber daya manusia yang dapat mengelola wisata sejarah sebagai wisata sejarah yang unik dalam rangka menarik minat wisatawan. Dipihak lain promosi tentang keberadaan objek wisata disuatu daerah itu sangat penting sehingganya dalam pengelolaan objek wisata sejarah Kota lama Semarang sekarang ini masih dalam tahap promosi antara orang per orang. Peranan Pemerintah umumnya dan pengelola khususnya dalam promosi objek wisata sangat diperlukan karena promosi objek wisata ini memerlukan kerja sama yang baik antara Pemerintah dan pemilik audio visual untuk menarik para pengunjung untuk datang ke objek wisata tersebut

\section{Alternatif Pemecahan Masalah}

Sesuai dengan permasalahan yang ada yaitu mengenai peranan promosi pariwisata untuk meningkatkan kunjungan wisatawan, maka penulis memberikan beberapa alternatif pemecahan masalah antara lain :

a. Peningkatan dan pelatihan promosi oleh SDM di lokasi terhadap obyek wisata sejarah di Kota lama Semarang, Kota Semarang

b. Menyediakan dan memperbaiki sarana dan kerja sama dengan Biro Perjalanan,travel biro setempat/lokal

c. Diadakannya promosi obyek wisata melalui berbagai macam media seperti: median TV, Radio atau selebaran-selebaran yang berisi tentang obyek wisata sejarah di Kota Semarang, terutama obyek wisata sejarah Kota lama Semarang yang unik.

d. Menyediakan fasilitas-fasilitas di sekitar obyek wisata, seperti tempat penginapan, tempat pembelian oleh-oleh atau saranasarana lain.

\section{Evaluasi Pemecahan Masalah}

a. Menjalankan strategi dan upaya yang tepat yang telah dirancang dalam rangka peningkatan peran SDM untuk promosi obyek wisata. 
Kelebihan :

1) Dapat menciptakan SDM yang tanggap terhadap obyek wisata sehingga dapat menjadi andalan Dinas Pariwisata

2) Akan menambah daya tarik wisatawan untuk datang berkunjung.

3) Para wisatawan yang berkunjung ke obyek wisata dapat merasa puas dan menikmati wisatanya.

Kekurangan :

1) Perlu biaya yang cukup banyak.

2) Perlu adanya kerja sama yang baik sebagai suatu tim untuk hasil yang memuaskan.

3) Membutuhkan seorang ahli atau supervisor bidang promosi agar tercipta hasil maksimal.

b. Menyediakan berbagai macam sarana untuk fasilitas, dan kerjasama travel untuk memudahkan wisatawan mengenal obyek wisata sejarah di Kota Semarang, terutama obyek wisata sejarah Kota lama Semarang.

Kelebihan :

1) Mempermudah transportasi para wisatawan, dan sarana sarana fasilitas di perbaiki dan ditambah
2) Transportasi yang mudah, dan fasilitas yang bagus dapat membuat orang bersemangat untuk berwisata ke lokasi tersebut.

Kekurangan :

1) Dibutuhkan banyak biaya dalam penciptaan sarana-sarana fasilitas, memerlukan waktu yang lama baik itu perencanaan dan pembangunan tersebut.

c. Perlu diadakan penambahan sarana publikasi tentang lokasi obyek wisata sejarah Kota lama di Kota Semarang

Kelebihan :

1) Dari berbagai segi obyek wisata dapat mudah dikenal dengan baik karena wisatawan mudah mengenal melalui televisi, radio, majalah maupun brosur brosur

2) Wisatawan dengan mudah mengakses lewat internet

3) Dapat menciptakan daya tarik yang difokuskan ke obyek wisata sejarah di Kota Semarang, terutama sejarah Kota lama Semarang

Kekurangan : 
1) Perlu adanya penambahan anggaran tentang promosi bagi Pengelola obyek wisata

2) Perlu adanya biaya penunjang yang besar dalam pembiayan rutinitas berlangganan internet, reklame dan spanduk2 serta reklame yang terus menerus terpasang dikota/ dijalan jalan.

d. Sarana dan fasilitas obyek wisata ditambah

Kelebihan :

1) Menambah aset pendapatan dari obyek wisata.

2) Para wisatawan yang mengujungi obyek wisata tersebut merasa lebih puas.

3) Masyarakat di sekitar obyek wisata dapat berperan serta misalnya, menjual oleh-oleh souvenir dan sebagainya.

Kekurangan :

1) Perlu adanya dana yang besar untuk penambahan fasilitas.

2) Masyarakat sekitar yang ikut berperan serta baik itu menjual oleh-oleh atau dalam hal fasilitas yang lain harus terkoordinir dengan baik.

3) Pengkordiniran fasilitas-fasilitas atau sarana yang ada harus lebih aktif agar tidak terjadi kesimpangsiuran.

\section{L.angkah-Iangkah Pemecahan Masalah}

Setelah mengetahui permasalahan yang ada maka perlu adanya langkahlangkah yang tepat untuk memecahkan masalah yang sedang dihadapi.

a. Obyek wisata yang dianggap memiliki potensi seperti mempunyai daya tarik dan nilai jual yang tinggi dikembangkan dengan membentuk suatu tim yang dikhususkan untuk perencanaan promosi obyek tersebut atau dengan mengontrak seorang supervisor di bidang obyek wisata sejarah

b. Sarana-sarana fasilitas yang baik itu dan jalan raya yang baik diciptakan agar minat para wisatawan untuk berkunjung lebih besar karena mudah dikenali

c. Sarana dan fasilitas obyek wisata tersebut diperbanyak dan lebih lengkap baik itu penginapan, café, tempat pembelian souvenir atau oleh-oleh. Dan juga para wisatawan yang berkunjung ke 
obyek wisata dapat merasa iebih puas terhadap pelayanan dan fasilitas obyek wisata.

\section{Hasil Yang Diharapkan}

Dari langkah-langkah yang diambil untuk pemecahan masalah maka hasil yang diharapkan dari usaha tersebut adalah:

a. Melalui pengembangan promosi potensi obyek wisata diharapkan akan tercipta sebuah obyek wisata andalan daerah yang dapat menjadi asset pendapatan daerah dan daya tariknya untuk para wisatawan sangat besar.

b. Sarana transportasi yang lengkap dan mudah dapat membuat bertambahnya para wisatawan yang datang ke lokasi obyek wisata sehingga dapat menambah pendapatan asset daerah itu sendiri.

c. Dengan bertambahnya tenaga kerja yang sudah terlatih diharapkan obyek wisata akan dapat dikoordinir dengan baik dan obyek wisata akan tetap terawat dengan baik

d. Dengan bertambahnya sarana dan fasilitas diharapkan para wisatawan yang datang lebih merasa puas dengan pelayanan yang ada dan dapat membuat para wisatawan untuk datang kembali ke obyek tersebut.

e. Peningkatan promosi tentang obyek wisata agar dapat memberikan informasi yang jelas tentang kondisi obyek wisata baik itu secara gambarannya maupun penjelasan tentang obyek wisata tersebut.

\section{KESIMPULAN}

Setelah melakukan penelitian, penulis akhirnya mengetahui bahwa masalah disebabkan oleh karena Pihak Pengelola maupun Pemerintah setempat kurang dapat menjalankan pentingnya peran promosi dalam melakukan peningkatan minat pengunjung terhadap obyek wisata sejarah yang ada di Obyek wisata sejarah Kota Semarang terutama wisata sejarah Kota lama. Hal ini dibuktikan dengan $66 \%$ dari responden menyatakan bahwa Pihak Pengelola belum dapat menjalankan perannya dengan maksimal.

Dengan adanya penyebab masalah di atas tentunya akan menimbulkan akibat masalah, dalam hal ini akibat 
yang ditimbulkan adalah menurunnya minat wisatawan pada obyek wisata. Wisatawan merasa kurang puas dan kurang tertarik terhadap obyek wisata atau secara keseluruhannya dapat disimpulkan bahwa wisatawan merasakan, pengenalan atau promosi pariwisata yang dilakukan oleh Pihak Pengelola masih kurang. Hal ini juga dibuktikan dengan table bukti masalah yang menunjukkan bahwa sebesar 51\% Pengunjung/ wisatawan yang datang merasa kurang puas dengan obyek wisata yang ada. Hal ini dapat dilihat pada atraksi wisata yang kurang, transportasi dan informasi untuk menuju ke lokasi wisata masih sangat sedikit, sarana pembelian souvenir atau oleh-oleh masih tergolong kurang dan kurangnya informasi atau promosi tentang obyek wisata yang ada.

\section{DAFTAR PUSTAKA}

Kodyat, dan Ramaini. 1992. Kamus Pariwisata dan Perhotelan, PT. Gramedia Widiasarana, Jakarta. Soekadijo, R. G. 1996. Anatomi Pariwisata, PT. Gramedia Pustaka Utama, Jakarta..
Wahab, Salah. 1997. Pemasaran Pariwisata, cetakan ketiga, PT. Pradnya Paramita, Jakarta.

Yasni, Sulkan. 1990. Kamus Bahasa Indonesia, cetakan kedua, Penerbit Bina Bangsa, Yogyakarta.

Yoeti, Oka. A. 1996. Pemasaran

Pariwisata Terpadu, cetakan pertama, Penerbit Angkasa, Bandung. 1990.

Pengantar

Pariwisata, PT. Pradnya Paramita, Jakarta.

2001. Tours and Travel
Management, cetakan
keenam, PT. Pradnya
Paramita, Jakarta.

Gun, 2007. Pariwisata Dalam Tata

Ruang Wilayah, Institusi Teknologi

Bandung, Bandung.

Pitana, 2009. Pengantar Ilmu

Pariwisata, Penerbit Andi, Yogyakarta.

Sumaatmadja, 1981. Study Geografi

Suatu Pendekatan dan Analisa

Keruangan, Alumi , Bandung 